\title{
Pengaruh Perhatian Orang Tua Terhadap Motivasi Belajar Anak Usia Dini Kelas Awal
}

\author{
Na'immatussholilah $^{1 凶}$, Hartatiana $^{1}$, Indah Dwi Sartika ${ }^{1}$ \\ (1) Pendidikan Anak Usia Dini, Universitas Islam Negeri Raden Fatah Palembang \\ naimah100807@gmail.com \\ Abstrak
}

Penelitian ini bertujuan untuk menguji bagaimana pengaruh orang tua terhadap motivasi belajar anak usia dini pad akelas 1 di SDN 1 Rejosari Kabupaten Oku Timur. Perhatian Orang Tua merupakan hal yang sangat diperlukan bagi seorang anak guna menjalani kehidupannya ehari hari. Perhatian dari orang tau secara otomatis akan membuat psikologi anak menjadi lebih baik dikarenakan anak yang masih memiliki jiwa yang labil biasanya memerlukan perhatian yang mampu mengontrol emosinya untuk tidak melakukan hal hal yang memiliki dampak negative terhadap dirinya. Selain itu dengan adanya perhatian dari orang tua juga secara otomatis akan menumbuhkan semangat anak dalam melakukan apapun termasuk dalam hal pembelajaran. pada penelitian ini, peneliti mencoba untuk menjelaskan bagaimana pengaruh perhatian orang tua terhadap motivasi belajar anak usia dini pada kelas 1 di SDN 1 Rejosari Kabupaten Oku Timur dimana setalah dilakukan beberapa pengujian statistic, diperoleh kseimpulan bahwa Perhatian Orang Tua memiliki pengaruh yang signifikan terhadap Motivasi Belajar Anak Usia Dini.

Kata Kunci : Anak Usia Dini, Motivasi Belajar, Perhatian Orang Tua

\section{Abstract}

This study aims to examine how the influence of parents on early childhood learning motivation in grade 1 at SDN 1 Rejosari, East Oku Regency. Parental attention is very necessary for a child to live his daily life. Attention from people tau will automatically make children's psychology better because children who still have unstable souls usually need attention that is able to control their emotions not to do things that have a negative impact on them. In addition, with the attention of parents, it will automatically foster children's enthusiasm in doing anything, including in terms of learning. In this study, researchers tried to explain how the influence of parental attention on learning motivation of early childhood in grade 1 at SDN 1 Rejosari, East Oku Regency where after several statistical tests were carried out, it was concluded that Parental Attention has a significant influence on Children's Learning Motivation. Early age.

\section{Keywords: Early Childhood, Learning Motivation, Parents Attention}

\section{PENDAHULUAN}

Setiap anak membutuhkan kasih sayang dan perhatian dari orang tua nya sehingga orang tua memiliki tanggung jawab yang besar terhadap anak nya.Bagi anak dunia pertama nya adalah keluarga, dimana anak belajar mengenal lingkungan di samping menanggapi dunia luar. Anak akan berinteraksi dengan anggota keluarga, teman sebaya dan lingkungan nya. Dari interaksi tersebut anak akan mengetahui keberadaan diri nya, dan keluarga sebagai contoh pertama adalah dalam menanamkan etika pada anak sejak dini agar dapat membedakan prilaku yang baik dan sesuai dengan norma dan nilai sosial.

Keluarga ialah dasar pembentukan karakter yang pertama bagi anak. Bagi anak lingkungan terdekat adalah keluarga nya. Banyak hal di dalam keluarga dan anak akan banyak belajar dari anggota keluarga nya terutama kedua orang tua nya. Dengan ini sebagai orang tua harus memperhatikan apa saja yang di butuhkan oleh anak. Interaksi pertama bagi anak adalah keluarga sedangkan interaksi yang kedua yaitu lingkungan sekitar.Selain keluarga, pembentukan karakter anak juga di pengaruhioleh lingkungan sekitar. Oleh karena itu, orang tua harus memberikan bimbingan dan pembinaan kepada anak nya untuk beradaptasi dengan lingkungan nya agar anak mengetahui apa yang kurang baik bagi diri nya. ( Raudhoh, 2018: 3) 
Perhatian orang tua merupakan salah satu faktor terpenting dalam perkembangan prilaku anak. Menurut purwanto (2011 : 24) mengatakan bahwa perhatian orang tua terhadap anak-anak nya adalah pendidikan yang di dasarkan pada rasa kasih sayang yang tulus (Ujang,Didih, dkk, 2019). Oleh karena itu kasih sayang orang tua terhadap anak-anak nya hendaklah kasih sayang yang sejati. Sehingga orang tua lebih mengutamakan kepentingan dan kebutuhan anak-anak dan mengesampingkan keinginan dan kesenangan sendiri.Dalam hal ini hendak nya kita harus tau bahwa pendidikan berdasarkan kasih sayang saja bisa mendatangkan bahaya.Kasih sayang orang tua harus di jaga jagan sampai berubah menjadi terlalu memanjakan anak sehingga anak kurang mandiri (Rohmat, 2010:4).

Dalam penelitian Rumbewas dkk (2018: 6),"peran orang tua dalam meningkatkan motivasi pesera didik " penelitian ini menggunakan pendekatan kualitatif. Penelitian kualitatif bertujuan untuk mendeskripsikan fenomena tertentu yang di alaami subjek melalui kata-kata.Dalam penelitian ini penulis menggnakan jenis penelitian deskriptif, yang bertujun untuk memdeskripsikan hal-hal nyata yang berhubungan dengan keadaan sebenar nya di nlapangan.Alat yang di gunakan dalam penelitian ini adalah kuesioner, pedoman awancaea dan dokumentasi. Setelah data terkumpul, akan di gunakan analisis deskriptif untuk analisis. Berdasarkan hasil observasi yang di laksanakn peneliti bahwa di lapangan masih banyak murid yang kurang memperhatikan guru dalam proses pembelajaran, mereka sibuk main dan mengobrol dengan teman. Upaya guru dalam mengatasi hal tersebut ialah dengan menegur mereka untuk memperhatikan apa yang disampaikan guru. Pada awalnya mereka diam dan memperhatikan, tetapi tidak lama kemudian mereka mulai melakukan aktivitas awal yang tidak memperhatikan guru dan sibuk dengan kegiatan mereka masing-masing.

Secara bahasa perhatian biasa diartikan sebagai minat yang di sukai dan di senangi. Di kamus besar bahasa Indonesia yang di susun oleh depdiknas di artikan bahwa perhatian ialah memperhatikan apa yang di perhatikan. Oleh karena itu perhatian difokuskan pada salah satu aspek psikologi yang menitik beratkan pada objek dari luar atau dalam individu. Perhatian ini sering digunakan untuk memprediksi tingkah laku atau perilaku manusia dalam kehidupan sehari-hari. Perhatian seperti ini akan menambah warna pada tingkah laku dan arah atau bahkan warna. Saat seseorang tertarik dengan suatu aktivitas, dia akan lebih memperhatikan. Oleh karena itu, ketika seorang siswa lebih memperhatikan suatu kelas, maka siswa tersebut akan bekerja keras untuk mendapatkan nilai yang baik melalui pembelajaran.

\section{METODE PENELITIAN}

Lokasi dalam penelitian ini akan dilaksanakan di SDN I Rejosari Kecamatan Belitang Mulya Kabupaten OKU Timur. Sekolah ini sudah berstatus negeri dan terakreditasi. Visi, misi dan tujuan juga tercatat jelas sehingga dapat menjadi patokan dalam mengembangkan mutu pendidikan yang ada di SDN I Rejosari. Pendidik yang ada di SDN I Rejosari ini juga sudah termasuk pendidik yang professional karena tingkat pendidikannya sarjana dan sudah berpengalaman dalam masa kerja yang tergolong lama.Hanya ada beberapa pendidik saja yang masih tergolong baru untuk masa kerjanya.

Pendekatan yang di gunakan dalam penelitian ini adalah pendekatan kuantitatif dengan jenis penelitian Ex-post Facto yaitu jenis penelitian yang variabel independenya merupakan peristiwa yang sudah terjadi. Sugiyono ( 2018 : 65) menyatakanbahwa "penelitian ex post facto adalah suatu penelitian yang dilakukan untuk meneliti peristiwa yang telah terjadi dan kemudian melihat ke belakang untuk mengetahui faktor-faktor yang dapat menimbulkan kejadian tersebut. Berdasarkan judul penelitian maka metode ex post facto sinkron dengan masalah yang di ambil oleh peneliti

Dalam penelitian ini mempunyai dua variabel yang akan dikaji yakni variabel $X$ peran orang tua, dan variabel Y motivasi belajar. Populasi dalam penelitian ini adalah seluruh siswa kelas I SDN 1 Rejosari dan orang tua siswa SDN 1 Rejosari, Kecamatan Belitang Mulya, Kabupaten OKU Timur, yang berjumlah 25 anak. Teknik pemilihan sampel yang akan dipakai ialah total sampling yang dimana sesuai dengan jumlah populasi, biasanya dilakukan jika populasi dianggap sedikit atau kurang dari 100. Sampel dalam penelitian ini ialah 25 anak yang ada di kelas I SDN I Rejosari. Teknik pengumpulan data yang akan digunakan dalam penelitian kali ini adalah wawancara, angket 
(kuesioner), Observasi, serta Dokumentasi. Teknik Analisis Data yang digunakan dalam Penelitian ini yaitu:

\section{Uji Normalitas}

Uji normalitas dimaksudkan untuk menguji normal tidaknya sampel.Uji normalitas data pada penelitian ini menggunakan teknik one-sample Kolmogorov-Smimov Test (KS-test).Pengujian normalitas menggunakan software SPSS menurut Wahid Sulaiman (2004 : 32) harus memenuhi syarat yaitu jika nilai Asymp. Sig. < $\alpha$ maka populasi bukan berasal dari populasi dengan distribusi tertentu, tetapi jika Asymp.Sig. > a maka populasi berasal dari populasi dengan distribusi tertentu.

\section{Uji Homogenitas}

Uji homogenitas digunakan untuk mengetahui apakah ada kesamaan varian dari kedua buah distribusi atau lebih.Uji homogenitas dilakukan untuk mengetahui apakah variable X dan $\mathrm{Y}$ homogen atau tidak.

\section{Uji Linieritas}

Uji lineritas menurut Zainal Arifin ( 2011 : 54), bertujuan untuk menguji apakah model linier yang diambil sudah sesuai dengan keadaannya atau tidak .Jika hasil pengujian menunjukkan model linier yang kurang sesuai maka harus menggunakan model nonlinier.

\section{Uji Hipotesis}

Uji Hipotesis dilakukan untuk mengetahui ada atau tidak pengaruh perhatian orang tua terhadap motivasi belajar anak usia dini pada kelas 1 di SDN 1 Rejosari kabupaten OKU Timur. Uji hipotesis yang digunakan peneliti yakni menggunakan teknik disebut dengan uji-t (t-test). Namun sebelum dilakukan uji hipotesis, penulis melakukan uji normalitas terlebih dahulu. Hal ini dilakukan bertujuan untuk mengetahui apakah data sampel berasal dari populasi yang berdistribusi norma serta berasal dari varian yang sama.

\section{HASIL DAN PEMBAHASAN}

Pada sub bahasan perhatian orang tua, peneliti terlebih dahulu akan menyajikan data determinasi simultan perhatian orang tua terhadap motivasi belajar anak sebagai berikut :

\section{Tabel 1.Uji Regresi Linier Berganda}

\begin{tabular}{l}
\multicolumn{3}{l}{ Model Summary } \\
\begin{tabular}{lllll} 
Model R & R Square & Adjusted R Square & Std. Error of the Estimate \\
\hline 1 & $.475^{\text {a }}$ & .225 & .192 & 4.43541 \\
\hline
\end{tabular}
\end{tabular}

a. Predictors: (Constant), perhatian orang tua

Data di atas adalaj olahan data untuk megetahui sejauh apa pengaruh variabel $X$ terhadap variabel $Y$ secara stimulant (keseluruhan). Pada data $R$ square di atas adalah 0,475 dimana nilai persentase nya adalah $47,5 \%$ dengan pertimbangan bahwa sisa persentase yang tidak didapat pada penelitian ini merupakan gambaran bahwa jawaban pernyataan perhatian yang diberikan kepada responden belum memberikan hasil yang baik dan juga menggambarkan penerapan perhatian orang tua terhadap anak masih minim.

Melihat data dan pengaruh perhatian orang tua, dalam hal ini peneliti menganalisa bahwa perhatian yang besar dari orang tua dapat mempengaruhi motivasi belajar anak.Karena seorang anak membutuhkan kasih sayang dan perhatian dari orang tua nya. Dengan perhatian maka anak akan merasa di hargai oleh orang tua nya dan bisa lebih semangat dalam belajar.

\section{SIMPULAN}

Perhatian yang besar dari orang tua dapat mempengaruhi motivasi belajar anak. Karena seorang anak membutuhkan kasih sayang dan perhatian dari orang tua nya. Dengan perhatian maka anak akan merasa di hargai oleh orang tua nya dan bisa lebih semangat dalam belajar. Perhatian sangat berpengaruh terhadap 
motivasi belajar anak terutama perhatian dari orang tua nya dan memberikan andil yang cukup besar dalam memotivasi anak

\section{DAFTAR PUSTAKA}

Arifin, Zainal. (2011). Penelitian Pendidikan Metode dan Paradigma Baru.Bandung: RosdaKarya

Shofiyah, H., \& Purnama, S. (2020). Kemitraan Guru dan Orang Tua dalam Menangani Anak yang Masih Ditunggu pada Jam Belajar. Journal of Education Research, 1(1), 18-27. https://doi.org/10.37985/joe.v1i1.3

Purwanto. 2011. Evaluasi Hasil Belajar. Yogyakarta: Pustaka Pelajar

Raudhoh (2018). Peran Keluarga Dalam Pendidikan Anak Usia Dini. Jurnal studi gender dan anak Vol.2 No.1

Rohmat. (2010). Keluarga dan pola pengasuhan anak. Jurnal Vol.5 No.1.

Selfia S. Rumbewas, Dkk ( 2018) Peran Orang Tua Dalam MiningkatkanMotivasi Belajar Peserta Didik di Sd Negeri Saribi

Sugiyono. 2018. Metode Penelitian Kuantitatif, Kualitatif, dan R\&D. Bandung: Alfabeta.

Ujang Didih dkk.(2019). Perhatian Orang Tua Dalam Pendidikan Keagamaan Anak di Rumah Hubungan nya Dengan Prilaku Mereka di Lingkungan Sekolah, Jurnal Atthulab, Vol IV No 1

Wahid, Sulaiman. (2004). Analisis Regresi Menggunakan SPSS: Contoh Kasus dan Pemecahan. Yogyakarta: Penerbit Andi. 